\title{
Character and interface shear strength of accreted ice on subcooled surfaces submerged in fuel
}

\author{
J. K.-W. Lam \\ joseph.lam@airbus.com \\ Airbus Operations \\ Filton, Bristol \\ UK \\ L. Lao \\ Cranfield University \\ Cranfield, Bedfordshire \\ UK \\ D. W. Hammond \\ Cranfield University \\ Cranfield, Bedfordshire \\ UK
}

\author{
J. P. Power \\ Airbus Operations \\ Filton, Bristol \\ UK
}

\section{ABSTRACT}

Sudden release of accreted ice in fuel systems could pose a serious challenge in aircraft operation. The resultant snowshower may reach the filter and fuel-oil heat exchanger, causing a restriction in fuel flow to the engine. It is fundamental to have an appreciation of the character and the interface shear strength of the accreted ice in aircraft fuel systems. This helps to recognise factors for the sudden release of the accreted ice and the intensity of the consequential snowshower. An experimental study was carried out to quantify the character and the interface shear strength of accreted ice on subcooled surfaces submerged in jet fuel. Ice was accreted on naked aluminium, painted aluminium and carbon fibre composite surfaces at various subcooled temperatures. The accreted ice was akin to fresh snow and exhibited soft and fluffy attributes. The character may be expressed quantitatively in terms of the porosity and was found to be c. 0.95 . The ice weakly adhered to the substrate surfaces, and the interface shear strength was found to be c. $0 \cdot 36 \mathrm{~Pa}$ and c. $2 \cdot 19 \mathrm{~Pa}$ at the top surface and at the vertical surface of a specimen block, respectively. It was not possible to detect any variation in the porosity and the interface shear strength for different types of surface finishes and differences in water affnity in fuels due to the crude approach in the estimation of these parameters. 


\section{NOMENCLATURE}

A

$d$

$f_{w}$

$g$

$m_{w}$

$n$

$\mathrm{Ra}$

$\mathrm{Re}$

T

$T_{s}$

$t$

$\bar{u}$

$V_{i}$

$V_{p}$

$V_{s}$

$V_{w}$

$x$

$v$

$\rho_{f}$

$\rho_{i}$

$\rho_{s}$

$\rho_{w}$

$\sigma_{a}$

$\sigma_{a, 0}$

$\sigma_{c}$

$\sigma_{\mathrm{c}, 0}$

$\sigma_{n}$

$\sigma_{w}$

$\tau_{a}$

$\tau_{c}$

$\tau_{w}$

$\tau_{w}^{h}$

$\tau_{w}^{v}$

$\tau^{h}$

$\tau^{v}$

$\phi_{a}$

$\phi_{c}$

AAIB

CFD

CRC

EASA

FOHE

Ic

Ih

ppm $v / v$ snow coverage area, $\mathrm{m}^{2}$

nozzle inner diameter, $\mathrm{m}$

water content fraction, -

gravitational acceleration, $\mathrm{ms}^{-2}$

mass of water, $\mathrm{kg}$

porosity, -

roughness, $\mu \mathrm{m}$

nozzle Reynolds number, -

temperature, ${ }^{\circ} \mathrm{C}$

surface temperature, ${ }^{\circ} \mathrm{C}$

snowpack thickness, $\mathrm{m}$

mean exit jet velocity, $\mathrm{ms}^{-1}$

ice volume, $\mathrm{m}^{3}$

pore volume, $\mathrm{m}^{3}$

snow volume, $\mathrm{m}^{3}$

water volume, $\mathrm{m}^{3}$

distance from the nozzle, $\mathrm{m}$

fuel kinematic viscosity, $\mathrm{m}^{2} / \mathrm{s}$

fuel density, $\mathrm{kg} / \mathrm{m}^{3}$

ice density, $\mathrm{kg} / \mathrm{m}^{3}$

snow density, $\mathrm{kg} / \mathrm{m}^{3}$

water density, $\mathrm{kg} / \mathrm{m}^{3}$

adhesion of the interface, $\mathrm{Pa}$

adhesive shear strength of solid ice, $\mathrm{Pa}$

cohesion of particles, $\mathrm{Pa}$

cohesive shear strength of solid ice, $\mathrm{Pa}$

normal stress, $\mathrm{Pa}$

shear stress due to weight, $\mathrm{Pa}$

interface shear strength, $\mathrm{Pa}$

internal shear strength, $\mathrm{Pa}$

wall shear stress, $\mathrm{Pa}$

horizontal surface wall shear stress, $\mathrm{Pa}$

vertical surface wall shear stress, $\mathrm{Pa}$

total shear stress at horizontal interface, $\mathrm{Pa}$

total shear stress at vertical interface, $\mathrm{Pa}$

interface friction angle, rad

internal friction angle, rad

Air Accidents Investigation Branch

Computational Fluid Dynamics

Co-ordinated Research Council

European Aviation Safety Agency

Fuel-Oil Heat Exchanger

Ice of cubic crystalline form

Ice of hexagonal crystalline form

parts per million by volume 
SG Specific Gravity

SLR Snow to Liquid Ratio

WAFCOLT Water in Aviation Fuel under COLd Temperature conditions

WBF Wegener-Bergeron-Findeisen

\subsection{INTRODUCTION}

On 17 January 2008, a twin-engine large commercial aircraft lost power to its engines and crash landed during approach to London Heathrow Airport. The investigation by the Air Accident Investigation Branch (AAIB) concluded that the most likely cause of the accident was that transient throttle changes during the aircraft final approach dislodged ice that had accumulated in the fuel system $^{(1-3)}$. As a consequence, chunks of ice reached the Fuel-Oil Heat Exchanger (FOHE) in the engine, causing a restriction in fuel flow which led to a reduction in available thrust. The investigation raised concerns on the lack of understanding of the nature and behaviour of water and ice in jet fuel and aircraft fuel system at low temperatures. It led the AAIB to make recommendations towards airworthiness authorities for coordinated research projects. The Safety Recommendation 2009-031 was made in March 2009 to address the lack of understanding on how ice forms in jet fuel and the properties of this ice ${ }^{(2)}$. Figure 1 shows the extract of the recommendation.

Since the incident at Heathrow in 2008, a number of researchers have investigated the behaviour of water in jet fuel at low temperatures ${ }^{(4-9)}$. Baena-Zambrana et $l^{(10)}$ provided a review of studies that have been done to date. In addition to these studies, mathematical models have been developed to investigate the effect of system architectures on water migration and accumulation in aircraft fuel systems ${ }^{(11,12)}$.

A research project titled 'WAFCOLT - Water in Aviation Fuel under Cold Temperature Conditions' was opened for tender by European Aviation Safety Agency (EASA) in 2010 in response to the recommendation ${ }^{(13)}$. The tender was awarded to Airbus and its research partner, Cranfield University, through their joint partnership led by Airbus. This paper reports on the findings from one of the work-packages of the research project.

\subsection{FUEL ICING}

When a volume of warm, water saturated jet fuel comes into contact with a subcooled surface of surface temperature $T_{s}<<0^{\circ} \mathrm{C}$, the fuel cools down to $T_{s}$. As the fuel cools down, water precipitates from the fuel as super fine water droplets of micron size ${ }^{(4,14)}$ since solubility of water in jet fuels decreases with deceasing temperature ${ }^{(15)}$. Lam et $a l^{(16)}$ reported fresh experimental solubility curves which shown some subtle different compared to the older data. The super fine water droplets make the fuel to change from a clear appearance to a cloudy appearance when cooled. Some of the water

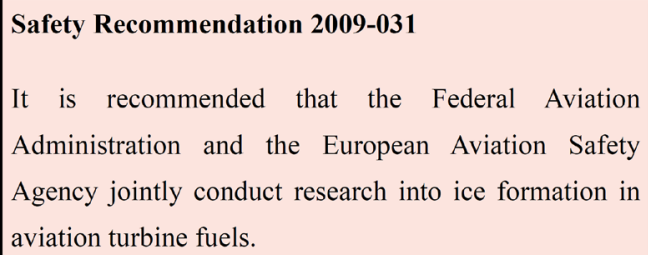

Figure 1. AAIB safety recommendation 2009-031. 


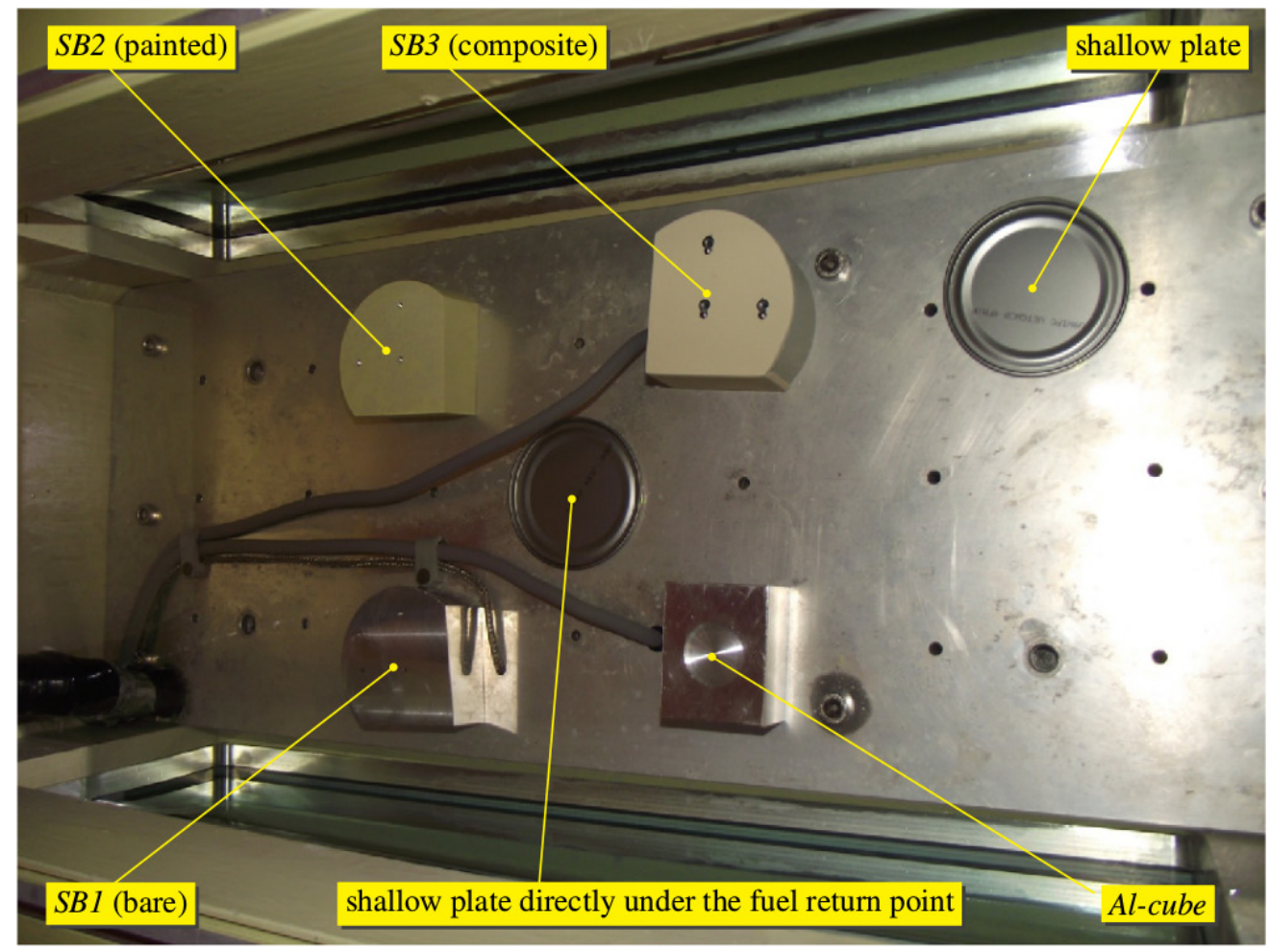

Figure 2. Aerial view of the four specimen blocks resting on the cooling plate in the test tank.

deposits directly on subcooled surfaces and freezes to form ice ${ }^{(5)}$. The appearance of the ice is akin to frost and snow ${ }^{(5)}$. In this paper, the term 'ice' is used for generic solid state water and may be interchanged, where appropriate, with the terms 'frost' and 'snow'.

The mass transfer of water from cloud of super fine water droplets to deposition on subcooled surfaces and the growth of ice crystals in jet fuels are attributed to the augmented WegenerBergeron-Findeisen (WBF) process and the Ostwald ripening process ${ }^{(7)}$. In an augmented WBF process, ice of hexagonal (Ih) crystalline form grows by deposition at the expense of ice of cubic (Ic) crystalline form. In an Ostwald ripening process, to reduce the interfacial free energy of the system, molecules on the surface of small, high curvature ice particles dissolve and diffuse away in fuel and deposit onto larger ice particles. The physics of the onset and the subsequent growth of ice on subcooled surfaces submerged in fuel are generally appreciated. However, the physical properties of the ice are not known. This study aims to quantify the ice physical properties in terms of the porosity and the interface shear strength. The interface shear strength is a key parameter to determine the critical ice thickness at the outbreak of a snowshower from ice release; and the ice porosity is used to determine the volume of water in the snowshower.

\subsection{TEST FUELS AND SPECIMEN BLOCKS}

Jet fuel does not have an exact chemical composition; it is produced to meet a set of properties. Its chemical composition will depend on the chemical species present in the parent crude oil 


\begin{tabular}{lccc} 
& \multicolumn{2}{c}{ Table 1 } & \\
Test fuels & \\
Fuel \& Specification & $\begin{array}{c}\text { Abbreviated } \\
\text { Name }\end{array}$ & $\begin{array}{c}\text { Aromatics } \\
{[\% \mathbf{\%} / \mathbf{v}]}\end{array}$ & Provenance \\
Coryton High & Coryton & $24 \cdot 1$ & Coryton Advanced Fuels, UK \\
$\begin{array}{l}\text { Aromatics Jet A-1 } \\
\text { Sasol Fully }\end{array}$ & Sasol & $12 \cdot 4$ & Sasol, South Africa \\
Synthetic Jet A-1 & & &
\end{tabular}

that come over in the physical separation in the kerosene boiling range and on further chemical treatments that may be required to meet the jet fuel specifications. The aromatics content of a fuel has been shown to have a major effect on the affnity of the fuel for water ${ }^{(10,16)}$. Table 1 summaries the two fuels used in this study. The two fuels represented the upper end and the lower end of the aromatics content in jet fuels. They were used to investigate the effect of water solubility on accreted ice character.

Three identical aluminium blocks were prepared. Each block has a different surface finish to investigate the effect of surface properties on interface shear strength. The three blocks were designated as $S B 1, S B 2$ and $S B 3$. In addition, an aluminium block, designated as $A l$-cube, which was initially used in commission tests, was also included in the study to provide additional surfaces for ice sampling. The bases of the four specimen blocks were left naked. This was to ensure all four blocks had a good thermal contact with the cooling plate that they were resting on. Table 2 shows a summary of the specimen blocks. An aerial view of the four specimen blocks resting on the cooling plate in the test tank is shown in Fig. 2.

\subsection{EXPERIMENTAL SETUP}

Figure 3 shows a schematic diagram of the general arrangement of the experimental setup. The experimental setup comprised of two parts, a test tank and a water replenishment system. The test tank consisted of a 20-litre glass-windowed aluminium tank with two cooling plates. The tank was of welded aluminium construction and thermally insulated with a removable lid. It had internal dimensions of $500 \mathrm{~mm}(\mathrm{~L}) \times 200 \mathrm{~mm}(\mathrm{~W}) \times 200 \mathrm{~mm}(\mathrm{H})$. Windows of $180 \mathrm{~mm}$

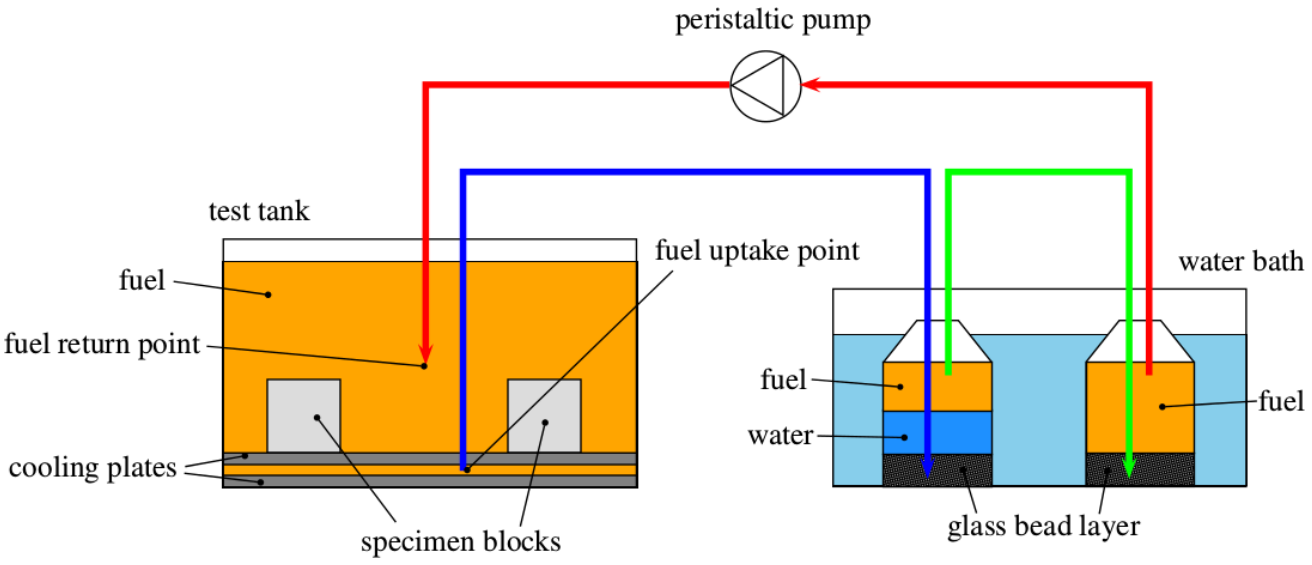

Figure 3. A schematic diagram showing the general arrangement of the experiment. 
$(\mathrm{H}) \times 400 \mathrm{~mm}(\mathrm{~W})$ were fitted in the long walls of the tank for observation. The windows were double glazed with a $6 \mathrm{~mm}$ thick toughened glass inner panel, a $10 \mathrm{~mm}$ air gap and a $8 \mathrm{~mm}$ thick toughened glass outer panel. Fuel was conditioned by two cooling plates, a fixed bottom cooling plate and a moveable upper cooling plate. The upper cooling plate was lowered to the bottom cooling plate to allow easy access to the specimen blocks in the tank for this study. Each cooling plate was chilled by its respective independent chiller. The chillers used a two-stage cascade cooling process, a Hermitique compressor CAE2417 with refrigerant R134 for the high temperature stage, and a Danfoss compressor S-15G with a binary refrigerant mixture for the low temperature stage.

The quantity of the fuel used would not have suffcient water in it to give a measurable amount of accreted ice. The fuel was therefore replenished with water during tests to ensure ice accretion would not be limited. The water replenishment system picked-up fuel at the void between the two cooling plates in the test tank. The fuel then passed through a two-stage water replenish system before returning to the test tank. The two stages represented by the two bottles on the suction side of the pump were in a warm water bath. Each bottle was $500 \mathrm{ml}$ in volume. The first bottle (the bottle on the left in Fig. 3) was made up with a $30 \mathrm{~mm}$ glass bead layer, then filled with de-ionised water to $60 \mathrm{~mm}$ from the base and finally topped with fuel to $90 \mathrm{~mm}$ from the base. The glass beads broke up the incoming fuel stream into small fuel droplets. This increased the fuel-water interface area for improved mass exchange. Fuel droplets warmed up as they rose through the water. Since water solubility in fuel increases with increasing temperature, water was absorbed by the warm fuel across the interfaces of rising fuel droplets as well as at the static free interface between the fuel and water layers. Fuel was then taken from the top of the fuel layer of the first bottle and fed to the second bottle. The second bottle (the bottle on the right in Fig. 3) was made up with a $30 \mathrm{~mm}$ glass bead layer at the base, then filled with just fuel to $90 \mathrm{~mm}$ from the base. The second bottle served as a buffer zone for capturing entrained water.

Dissolved water is water dissolved in fuel as a homogeneous mixture composed of only one phase. It is regarded as another fuel constituent and is not considered a contaminant as long as it is remained in a dissolved state ${ }^{(15)}$. Due to the dynamic of fuel flow through the water layer in the first bottle of the water replenishment system, water may be entrained as fine droplets in fuel. These droplets suspended in fuel as a heterogeneous mixture of two immiscible phases.

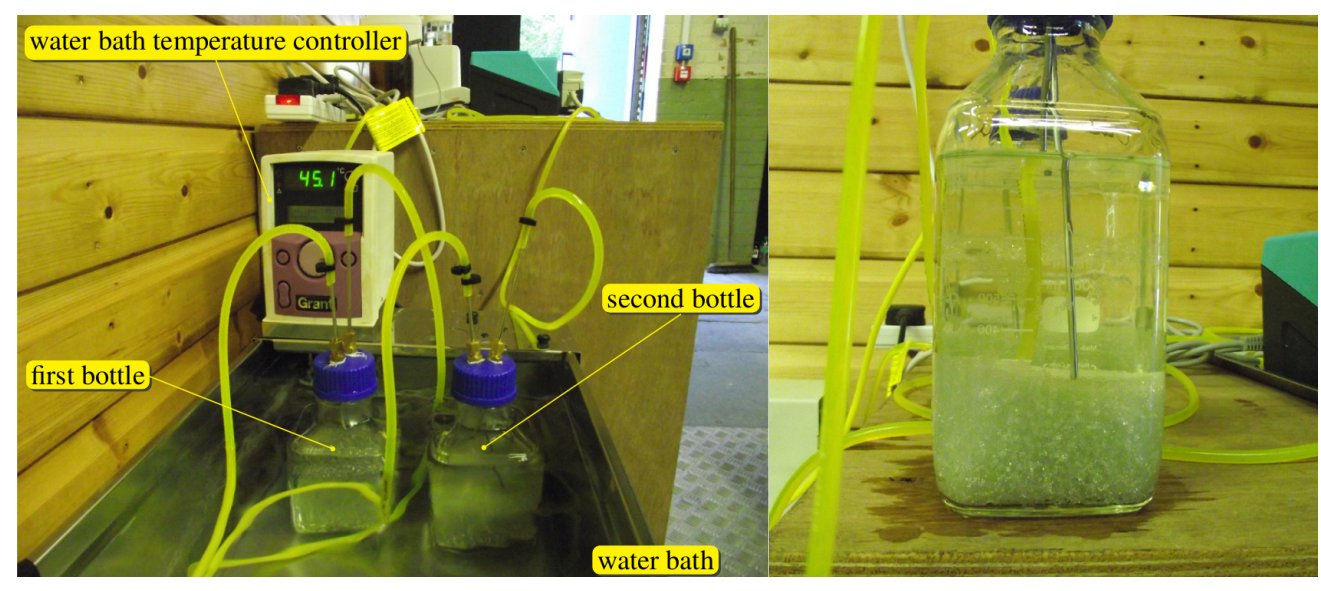

(a) Water replenishment system in operation

(b) Second bottle taken out of the water bath to show the fuel clarity

Figure 4. Water replenishment system. 


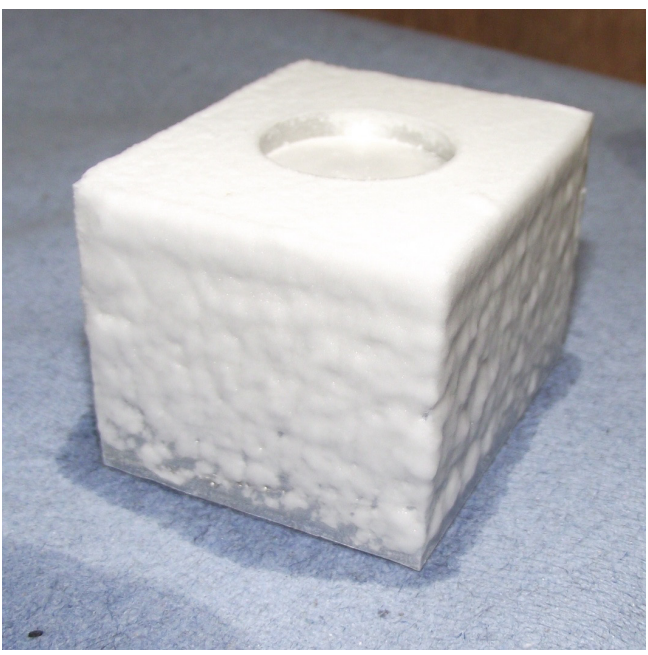

Figure 5. Al-cube specimen block covered with accreted ice.

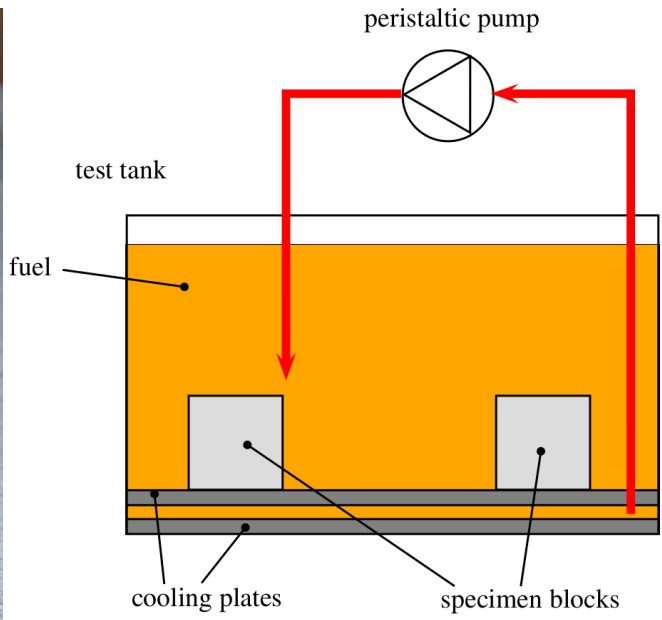

Figure 6. A schematic diagram showing the general arrangement of the jet method.

They make the fuel to have a dull, hazy, or cloudy appearance. Entrained water is regarded as a fuel contaminant. The second bottle was used to minimise the risk of entrained water carried over into the test tank. Figure 4 shows the water replenishment system in operation. The clarity of the fuel in the second bottle at the end of a test (Fig. 4(b)) suggested that there was a negligible amount of entrained water in the fuel. It was important that entrained water was kept to a minimum as much as possible so that the current study was focused on ice accretion from dissolved water. The water replenishment system had a fuel flowrate of $200 \mathrm{ml} / \mathrm{min}$ (or 1.67 fuel changes per hour) to minimise the impact of flow dynamic on ice accretion. The system was relatively ineffcient, since the fuel returned was only topped up a fraction of the saturated value. A large fuel change through the system was required to build up suffcient accreted ice for evaluation. With a low flowrate through the water replenishment system, this means a long runtime of c. $168 \mathrm{~h}$ was needed for each test.

\subsection{RESULTS AND DISCUSSION}

\subsection{Snow character}

Figure 5 shows the $A l$-cube specimen block covered with accreted ice. The accreted ice appeared to be soft and fluffy. It was much akin to snow and frost. Samples of accreted ice from specimen blocks were collected in sampling containers and let to melt in a warm environment. The samples were sealed immediately after the collection to prevent any water loss from the samples to the ambient or water gain to the samples from the ambient. Melt water settled out from the samples over time. The pooled water at the bottoms of the sampling containers was then frozen to solid ice in a freezer. When the water was frozen to solid, fuel was then drained out from the samples. For each sample, the mass of water $m_{w}$ was measured. The mass of fuel was not measured since it would not be a reliable parameter. Fuel might be squeezed out from the sample when the snow matrix collapse as it was lifted off from the fuel or excess fuel may be scooped up when taking the sample. 


\section{Table 2 \\ Specimen blocks}

$\begin{array}{ll}\text { Name } & \text { Description } \\ \text { SB1 } & \text { Naked aluminium: smooth surface finish } \\ \text { SB2 } & \text { Painted aluminium: top and vertical surfaces were painted } \\ & \text { with a fuel tank primer } \\ \text { SB3 } & \begin{array}{l}\text { Carbon fibre composite: fitted composite strips were bonded to the } \\ \text { top and one of the flat vertical surfaces of the aluminium block }\end{array} \\ \text { Al-cube } & \text { Naked aluminium: rough surface finish }\end{array}$

Table 3

Test conditions and snow densities

Parameter

Fuel

Cooling plate temperature $\left[{ }^{\circ} \mathrm{C}\right]$

Temperature at $3 \mathrm{~cm}$

above the cooling plate $\left[{ }^{\circ} \mathrm{C}\right]$

Room temperature $\left[{ }^{\circ} \mathrm{C}\right]$

Mass of water $m_{w}[\mathrm{~g}]$

Snow coverage area $A\left[\mathrm{~mm}^{2}\right]$

Snow thickness at top edge [mm]

Mean snow thickness $t$ [mm]

Snow volume $V_{s}\left[\mathrm{~mm}^{3}\right]$

Snow density $\rho_{s}\left[\mathrm{~kg} / \mathrm{m}^{3}\right]$

Mean snow density $\rho_{s}\left[\mathrm{~kg} / \mathrm{m}^{3}\right]$ $\begin{array}{llll} & 2 & 3 & \text { Sample }\end{array}$

Coryton Sasol Sasol Coryton

$\begin{array}{llll}-24 \cdot 2 & -24 \cdot 2 & -24 \cdot 2 & -19 \cdot 0\end{array}$

$\begin{array}{llll}-5 \cdot 1 & -5 \cdot 1 & -5 \cdot 1 & -3 \cdot 4\end{array}$

$17 \cdot 7 \quad 17 \cdot 7 \quad 17 \cdot 7 \quad 16 \cdot 9$

$\begin{array}{llll}0.530 & 0.341 & 0.298 & 0 \cdot 131\end{array}$

$4,620 \quad 4,104 \quad 2,378 \quad 1,176$

$6 \cdot 0 \quad 4 \cdot 0 \quad 5 \cdot 0 \quad 5 \cdot 0$

$\begin{array}{llll}3.0 & 2 \cdot 0 & 2 \cdot 5 & 2 \cdot 5\end{array}$

$13,860 \quad 8,208 \quad 5,945 \quad 2,940$

$38 \cdot 2 \quad 41 \cdot 5 \quad 50 \cdot 1 \quad 44 \cdot 6$

$43 \cdot 6$

The accreted ice snow volume $V_{s}$ was calculated from the accreted ice snow coverage area $A$ and the accreted ice snowpack thickness $t$. The snow coverage area $A$ was taken from the known geometric dimensions of the specimen blocks. The snowpack thickness $t$ was estimated with the aid of a snow depth gauge. The snow density $\rho_{s}$ was then calculated using Equation A.2 with the mass of water $m_{w}$ and the snow volume $V_{s}$. Table 3 shows the test conditions and the snow densities for 4 samples. The snow densities $\rho_{s}$ ranged from c. 38 to $50 \mathrm{~kg} / \mathrm{m}^{3}$ and with a mean of c. $44 \mathrm{~kg} / \mathrm{m}^{3}$. From the variation of snow densities observed and taking account of measurement errors, correlation between aromatics content and snow density was found to be insignificant. The batch-to-batch variation of fuel would have no effect on the accreted ice character.

Snow density $\rho_{s}$ is a parameter for quantifying the ice character, among others, porosity $n$, water content fraction $f_{w}$, snow-to-liquid ratio (SLR) and specific gravity (SG). The interrelationships of these parameters are presented in Appendix A for clarity. The SLR is a well defined parameter commonly used in atmospheric physics ${ }^{(17-20)}$ to quantity snow character. A snow density $\rho_{s}$ of c. $44 \mathrm{~kg} / \mathrm{m}^{3}$ is equivalent to a SLR of c. 23 . This would be classified as ultra light snow ${ }^{(21)}$. Measurements of freshly fallen snow in atmosphere may vary with SLR ranged from 3 to $100^{(17-19,22)}$. The distribution of freshly fallen snow from dataset in Roebber et $a l^{(22)}$ 


Distribution of freshly fallen snow from dataset in Roebber et a(2)
$\begin{array}{ccc}\text { Snow Category } & \text { SLR Band } & \text { Events [\%] } \\ \text { Very Heavy } & \text { SLR } \leq 5 \cdot 5 & 6 \\ \text { Heavy } & 5 \cdot 5<\text { SLR } \leq 8 \cdot 5 & 11 \\ \text { Average } & 8 \cdot 5<\text { SLR } \leq 12 \cdot 5 & 28 \\ \text { Light } & 12 \cdot 5<\text { SLR } \leq 17 \cdot 5 & 26 \\ \text { Very Light } & 17 \cdot 5<\text { SLR } \leq 22 \cdot 5 & 16 \\ \text { Ultra Light } & 22 \cdot 5<\text { SLR } & 13\end{array}$

Table 5

Typical physical properties of water and Jet A-1

\begin{tabular}{|c|c|c|c|}
\hline Parameter & Value & Unit & Reference/Remarks \\
\hline Ice density $\rho_{i}$ at $0^{\circ} \mathrm{C}$ & $916 \cdot 7$ & $\mathrm{~kg} / \mathrm{m}^{3}$ & \multirow{2}{*}{ Haynes et $a l^{(54)}$} \\
\hline Water density $\rho_{w}$ at $4^{\circ} \mathrm{C}$ & $999 \cdot 8$ & $\mathrm{~kg} / \mathrm{m}^{3}$ & \\
\hline Fuel density $\rho_{f}$ at $-10^{\circ} \mathrm{C}$ & $831 \cdot 1$ & $\mathrm{~kg} / \mathrm{m}^{3}$ & Estimated with reference to \\
\hline $\begin{array}{l}\text { Fuel kinematic } \\
\text { viscosity } v \text { at }-10^{\circ} \mathrm{C}\end{array}$ & $2 \cdot 729$ & $\mathrm{~mm}^{2} / \mathrm{s}$ & $\begin{array}{l}\text { measured values provided by the } \\
\text { fuel supplier and adjusted in line } \\
\text { with the trends given in } \mathrm{CRC}^{(15)} \text { for } \\
\text { the specified temperature }\end{array}$ \\
\hline
\end{tabular}

is shown in Table 4. The occurrence of ultra light snow in atmosphere is not at all uncommon. Many factors may contribute to SLR, among others, crystal shape and size, degree of rimming and aggregation of the snow flake, melting and sublimation, and compaction and snowpack metamorphism $^{(22)}$. Ice crystal shape or habit may take the following forms, among others, plate, needle, hollow column, sector plate and dendrite ${ }^{(23)}$. Rimming is an ice crystal growth process in which supercooled water droplets collide with the crystal and freeze to $i^{(24)}$.

The effective weight of ice in fuel may be a contributing factor for the relative high SLR for the accreted ice found in this study. Table 5 shows some typical physical properties of water and Jet A-1. Ice is only slightly denser than fuel. The density ratio of ice to fuel is c. 1.1. This almost weightlessness effect allows ice crystals in fuel to grow in a very open structure without fracturing their dendrites under their own weight. This leads to a relatively high SLR.

Another factor affecting SLR is compaction due to prevailing fluid dynamic condition. Surface wind can affect the SLR of fallen snow on the ground in the atmosphere. At a critical wind speed and over, ice crystals at the surface may be fractured mechanically during saltation and thereby reducing the SLR of the snowpack. The critical wind speed is quoted to be $9 \mathrm{~ms}^{-1}$ by Roebber $e t$ $a l^{(22)}$ and Ware et $a l^{(17)}$, and $4 \mathrm{~ms}^{-1}$ by Meløysund et $a l^{(25)}$. Since the accreted ice in this study was formed in a pseudo-static condition, the prevailing fluid dynamic condition could not support saltation and the SLR of the accreted ice thereby remained high.

\subsection{Shear strength}

A number of apparatuses for measuring the shear strength of snow in both controlled laboratories and in-situ field tests has been reported. They included a direct simple shear apparatus ${ }^{(26,27)}$, a shear frame tester ${ }^{(28-30)}$, a centrifuge adhesion tester ${ }^{(31)}$ and a vibration simple shear apparatus ${ }^{(32)}$. Although these apparatuses were applicable to the current study, however, their adaptation to 
measure the shear strength of accreted ice on subcooled surfaces submerged in fuel was proved to be challenging. The diffculties were:

- the test tank internal dimensions imposed a very tight limit on the apparatus size for in-situ shear strength measurements;

- the available accreted ice quantity was too low to be of any effective use to these apparatuses; and

- since the accreted ice was very delicate, it was not practical to transfer it out of the test tank for shear strength measurements.

A jet method, which overcame these challenges, was identified as one possible test method for this diffcult application. The technique of fluid jetting ${ }^{(33-39)}$ for interface shear strength quantification is an established approach. The jet method used in the current study was a crude implementation to provide an order of magnitude value. Figure 6 shows a schematic of the general arrangement of the jet method used. A peristaltic pump took fuel from the test tank and returned the fuel as a jet at a selected target through a specially designed nozzle. The pump had a digital controller to regulate the flow rate from 6 to $800 \mathrm{ml} / \mathrm{min}$ which delivered a mean exit jet velocity $\bar{u}$ from $0 \cdot 024$ to $3 \cdot 2 \mathrm{~ms}^{-1}$. The free jet was directed vertically downward and with the nozzle positioned at a distance $x=10 \mathrm{~mm}$ from the target. The free jet split into a vertical wall jet and a horizontal wall jet at the target as shown graphically in Fig. 7. The vertical wall jet and the horizontal wall jet exert a shear force on the accreted ice on the vertical surface and the top surface of the specimen block, respectively.

Following Ackerman et $a l^{(38)}$, the wall shear stress $\tau_{w}$ obtained for flow over a flat surface would be approximately proportional to the detachment forces acting on the accreted ice on that surface. The interface shear strength $\tau_{a}$, therefore, may be inferred in part from the wall shear stress $\tau_{w}$. A computational fluid dynamics (CFD) study was conducted to yield the wall shear stress $\tau_{w}$ values exerted by the jets on the vertical surface and the top surface of the specimen block. This is to support the determination of the interface shear strength $\tau_{a}$. Details of the CFD study are given in Appendix B. Table 6 shows a summary of the wall shear stresses from the CFD study. The nozzle Reynold number Re was defined as:

$$
\operatorname{Re}=\frac{\bar{u} d}{v}
$$

Here $d=2 \cdot 3 \mathrm{~mm}$ was the nozzle inner diameter and $v$ the fuel kinematic viscosity (Table 5).

On a vertical surface, the weight of the accreted ice acts in the same direction as the shear force exerted by the vertical wall jet. The total shear stress at the vertical interface $\tau^{v}$ may be expressed as:

\section{Table 6}

\begin{tabular}{cccc}
\multicolumn{4}{c}{ Wall shear stress induced by the jets } \\
$\overline{\boldsymbol{u}}$ & $\mathbf{R e}$ & $\boldsymbol{\tau}_{\boldsymbol{w}}^{h}$ & $\boldsymbol{\tau}_{\mathbf{w}}^{\mathbf{v}}$ \\
& $(\mathbf{E q n} . \mathbf{1})$ & $(\mathbf{C F D})$ & $(\mathbf{C F D})$ \\
{$\left[\mathbf{m s}^{-1}\right]$} & {$[-]$} & {$[$ Pa] } & {$[$ Pa] } \\
0.024 & 20.23 & 0.09 & 0.09 \\
0.040 & 33.71 & 0.36 & 0.36 \\
0.080 & 67.42 & 1.86 & 2.01 \\
0.160 & 134.85 & 6.97 & 8.35
\end{tabular}




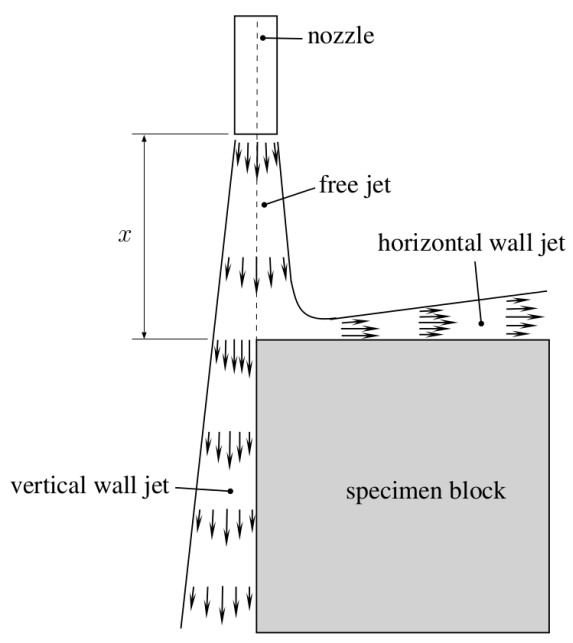

Figure 7. A schematic diagram showing the free jet splits into a vertical wall jet and a horizontal wall jet.

$$
\begin{gathered}
\tau^{v}=\tau_{w}^{v}+\sigma_{w} \\
\sigma_{w}=\left(\rho_{i}-\rho_{f}\right) f_{w} g t
\end{gathered}
$$

Here $\sigma_{w}$ is the shear stress induced by the snowpack weight; $\rho_{i}$ the ice density; $\rho_{f}$ the fuel density; $f_{w}$ the water content fraction; $g$ the gravitational acceleration; and $t$ the snowpack thickness. On a horizontal surface, the weight of the accreted ice acts in an orthogonal direction to the shear force exerted by the horizontal wall jet. The weight, thereby, does not contribute to the shear stress at the ice-substrate interface. The total shear stress at the horizontal interface $\tau^{h}$ is simply:

$$
\tau^{h}=\tau_{w}^{h}
$$

Figure 8 shows the effect of various jet velocities on the accreted ice. The horizontal wall jet was able to clear a patch of snowpack around the impingement point on the top surface of the specimen block with a moderate mean exit jet velocity $\bar{u}$ of $0.040 \mathrm{~ms}^{-1}$ (Fig. 8(b)). With this moderate mean exit jet velocity $\bar{u}$ the vertical wall jet made no impression on the snowpack at the top of the vertical surface of the specimen block. With the mean exit jet velocity $\bar{u}$ increased to $0.080 \mathrm{~ms}^{-1}$, the snowpack at the top of the vertical surface was shifted (Fig. 8(c)). A path of 10 to $15 \mathrm{~mm}$ in length was cut through in the snowpack at the top of the vertical surface of the specimen block (Fig. 8(d)) with the mean exit jet velocity $\bar{u}$ increased to $0 \cdot 160 \mathrm{~ms}^{-1}$. When the

\begin{tabular}{lcccc}
\multicolumn{5}{c}{ Table 7} \\
Accreted ice interface shear strength & \\
& $\overline{\boldsymbol{u}}$ & $\boldsymbol{\tau}_{\boldsymbol{w}}$ & $\boldsymbol{\sigma}_{\boldsymbol{w}}$ & $\boldsymbol{\tau}_{a}$ \\
& & $(\mathbf{C F D})$ & $(\mathbf{E q n} .3)$ & $(\mathbf{E q n . ~ 2 / 4 )})$ \\
& {$\left[\mathbf{m s}^{-1}\right]$} & {$[\mathbf{P a}]$} & {$[\mathbf{P a}]$} & {$[\mathbf{P a}]$} \\
Top surface & $0 \cdot 040$ & $0 \cdot 36$ & - & $0 \cdot 36$ \\
Vertical surface & $0 \cdot 080$ & $2 \cdot 01$ & $0 \cdot 18$ & $2 \cdot 19$
\end{tabular}




\section{Table 8}

Adhesive shear strength of solid ice. $R a=$ roughness;

\section{$T=$ temperature; $\sigma_{a, 0}=$ adhesive shear strength of solid ice}

\begin{tabular}{|c|c|c|c|c|}
\hline Substrate & $\underset{[\mu \mathrm{m}]}{\mathbf{R a}}$ & $\begin{array}{c}T \\
{\left[{ }^{\circ} \mathbf{C}\right]}\end{array}$ & $\begin{array}{c}\boldsymbol{\sigma}_{a, 0} \\
{[\mathbf{M P a}]}\end{array}$ & Reference \\
\hline Aluminium & $0 \cdot 7$ & -10 & 0.51 & Fortin $e t a l^{(42)}$ \\
\hline Aluminium & $\begin{array}{l}15 \cdot 6 \\
1 \cdot 11\end{array}$ & $\begin{array}{c}-6 \\
-20 \\
-6 \\
-20\end{array}$ & $\begin{array}{c}0 \cdot 0381 \\
0 \cdot 164 \\
0 \cdot 0451 \\
0 \cdot 2442\end{array}$ & Dong et $a l^{(46)}$ \\
\hline Copper & $\begin{array}{c}14 \cdot 03 \\
0 \cdot 4\end{array}$ & $\begin{array}{c}-6 \\
-20 \\
-6 \\
-20\end{array}$ & $\begin{array}{l}0 \cdot 0247 \\
0 \cdot 0736 \\
0 \cdot 0284 \\
0 \cdot 1085\end{array}$ & \\
\hline Aluminium & $\begin{array}{l}241 \\
212 \\
181\end{array}$ & -10 & $\begin{array}{c}0 \cdot 08 \\
0 \cdot 10 \\
0 \cdot 375\end{array}$ & Kulinich and Farzaneh ${ }^{(43)}$ \\
\hline $\begin{array}{l}\text { Aluminium } \\
\text { Stainless steel } \\
\text { Copper } \\
\text { Polycarbonate }\end{array}$ & - & -10 & $\begin{array}{l}0 \cdot 184 \\
0 \cdot 441 \\
0 \cdot 648 \\
0 \cdot 600\end{array}$ & Kibler $^{(47)}$ \\
\hline Stainless steel & $2 \cdot 14$ & -10 & $1 \cdot 5$ & Palacios et $a l^{(55)}$ \\
\hline Stainless steel & $\begin{array}{l}\text { rough } \\
\text { polished } \\
\text { mirror }\end{array}$ & $-4 \cdot 5$ & $\begin{array}{l}0 \cdot 598 \\
0 \cdot 265 \\
0 \cdot 0667\end{array}$ & Jellinek $^{(56)}$ \\
\hline Stainless steel & $0 \cdot 22$ & $\begin{array}{l}-10 \\
-15 \\
-20\end{array}$ & $\begin{array}{l}0 \cdot 77 \\
1 \cdot 15 \\
1 \cdot 42\end{array}$ & \\
\hline $\begin{array}{l}\text { Epoxy polyamide primer } \\
\text { coated surface }\end{array}$ & $0 \cdot 53$ & $\begin{array}{l}-10 \\
-15 \\
-20\end{array}$ & $\begin{array}{l}0 \cdot 34 \\
0 \cdot 57 \\
0 \cdot 59\end{array}$ & Gouni $^{(57)}$ \\
\hline $\begin{array}{l}\text { Polyurethane top } \\
\text { coat surface }\end{array}$ & $0 \cdot 52$ & $\begin{array}{l}-10 \\
-15 \\
-20\end{array}$ & $\begin{array}{l}0 \cdot 29 \\
0 \cdot 37 \\
0 \cdot 47\end{array}$ & \\
\hline
\end{tabular}

total shear stress at the interface ( $\tau^{h}$ or $\tau^{w}$ ) exceeds the interface shear strength $\tau_{a}$, the accreted ice would be sheared off from the substrate. This occurred at mean exit jet velocity $\bar{u}$ of $0 \cdot 040 \mathrm{~ms}^{-1}$ for the accreted ice on the top surface of the specimen block (Fig. 8(b)), and at mean exit jet velocity $\bar{u}$ of $0.080 \mathrm{~ms}^{-1}$ for the accreted ice on the vertical surface of the specimen block (Fig. 8(c)). Table 7 shows the interface shear strength $\tau_{a}$ of the accreted ice. A snowpack thickness $t$ of $c .5 \mathrm{~mm}$ was used to calculate the shear stress due to weight $\sigma_{w}$ in the table. The discrepancy between the interface shear strength for accreted ice on the top surface and that on the vertical surface may be due to variation in the accretion mechanism and ice morphology. Further investigation is needed. 


\section{Table 9 \\ Relationships of shear strength and snow character}

Reference
$\begin{aligned} & \text { Yamanoi and } \\ & \text { Endo }^{(50)} \\ & \text { Abe } \text { et } l^{(28)}\end{aligned}$
$\tau_{c}=9 \cdot 40 \times 10^{-4} \rho_{s}^{2 \cdot 91}$

\section{Remarks}

Derived from snow with densities range from $50 \mathrm{~kg} / \mathrm{m}^{3}$ to $500 \mathrm{~kg} / \mathrm{m}^{3}$.

Derived from snow with densities range from $150 \mathrm{~kg} / \mathrm{m}^{3}$ to $350 \mathrm{~kg} / \mathrm{m}^{3}$.

$n$ is the porosity; $\sigma_{c, 0}$ and $\sigma_{a, 0}$ the cohesive shear strength and the adhesive shear strength of solid ice $(n=0)$. The relationships do not agree with the strength data at higher porosities.

Following Föhn ${ }^{(40)}$ and Mellor ${ }^{(41)}$, with reference to Coulomb's law (Appendix C), the interface shear strength $\tau_{a}$ is derived from two components, adhesive shear strength $\sigma_{a}$ and friction resistance $\sigma_{n} \tan \phi_{a}$ (Equation C.1). Similarly, the inernal shear strength $\tau_{c}$ is derived from cohesive shear strength $\sigma_{c}$ and friction resistance $\sigma_{n}$ Tan $\phi_{c}$ (Equation C.2). Since there was no normal load acting on the accreted ice on the vertical surface, i.e. $\sigma_{n}=0 \mathrm{~Pa}$, the friction component of the interface shear stress was nil. This implies that the interface shear strength $\tau_{a}$ is the same as the adhesive shear strength $\sigma_{a}$, i.e. $\tau_{a}=\sigma_{a}$, for the accreted ice on the vertical surface.

For comparison, Table 8 shows the interface shear strengths of solid ice on various substrates. The term solid ice is used to refer to ice with porosity $n=0$ or close to it. Fortin et $a l^{(42)}$ commented that the large range and the variation in the reported interface shear strength data throughout literature are due to a number of factors, such as different testing conditions and experimental techniques, as well as surface finish, size, and type of substrate being used, making it diffcult to quantify the interface shear strength of ice with an absolute value. Despite the uncertainty of the absolute values, some underlying trends have been reported. Kulinich and Farzaneh ${ }^{(43)}$ observed an increase in interface shear strength with a decrease in substrate surface roughness. They attributed the phenomenon to Cassie and Baxter ${ }^{(44)}$ wetting mode and Wenzel $^{(45)}$ wetting mode for rough and smooth surfaces, respectively. Dong et al ${ }^{(46)}$ observed that interface shear strength of ice on aluminium and copper plates increases with decreasing temperature to around $-20^{\circ} \mathrm{C}$. At temperatures lower than $-20^{\circ} \mathrm{C}$, the interface shear strength remains constant. On the other hand, the data from Kibler ${ }^{(47)}$ suggested that temperature had very little effect on the interface shear strength.

The interface shear strength of the accreted ice on subcooled surfaces submerged in fuel in this study is several orders of magnitude smaller than those tabulated in Table 8. Since the accreted ice in this study has a very high porosity, the number of interfacial bonds across the interface would be limited. The interface shear strength of the accreted ice on subcooled surfaces submerged in fuel is therefore expected to be much smaller than that for solid ice. Relationships between snow density (or porosity) and shear strength have been studied by a number of researchers ${ }^{(26,28,32,48-51)}$. A number of these relationships is shown in Table 9. Of these relationships, only the correlation of Yamanoi and Endo ${ }^{(50)}$ is plausibly applicable for the 


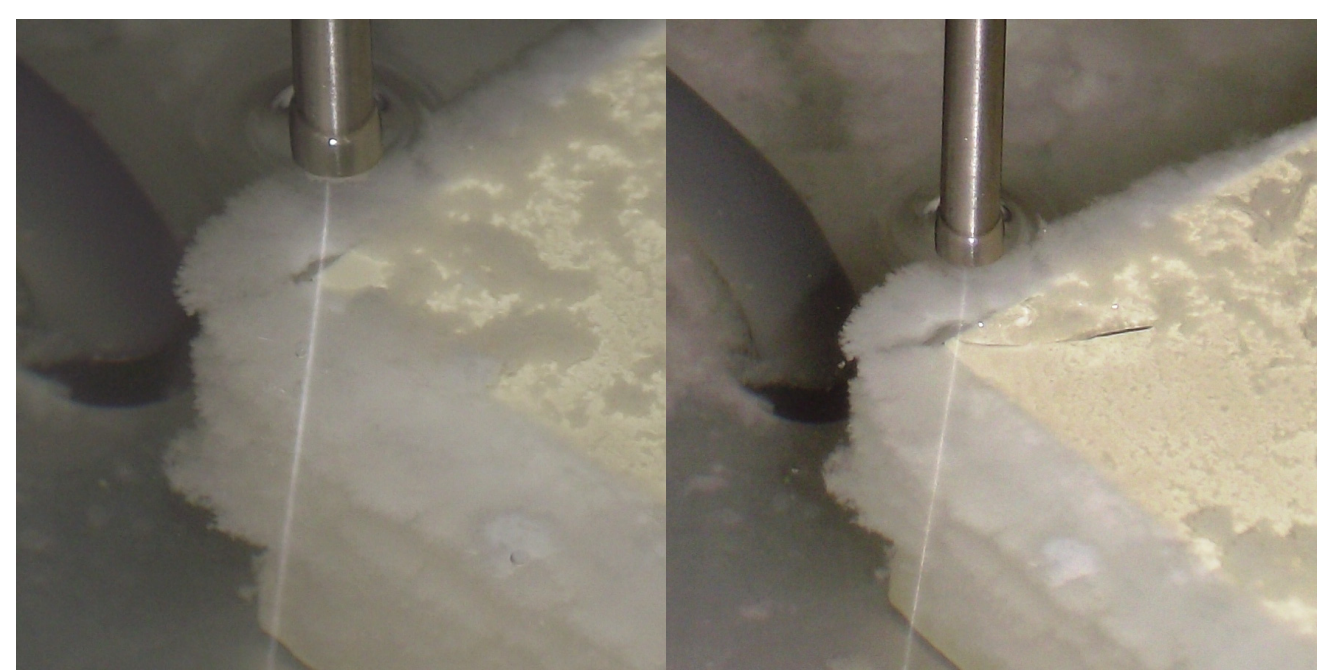

(a) $\bar{u}=0.024 \mathrm{~ms}^{-1}$

(b) $\bar{u}=0.040 \mathrm{~ms}^{-1}$

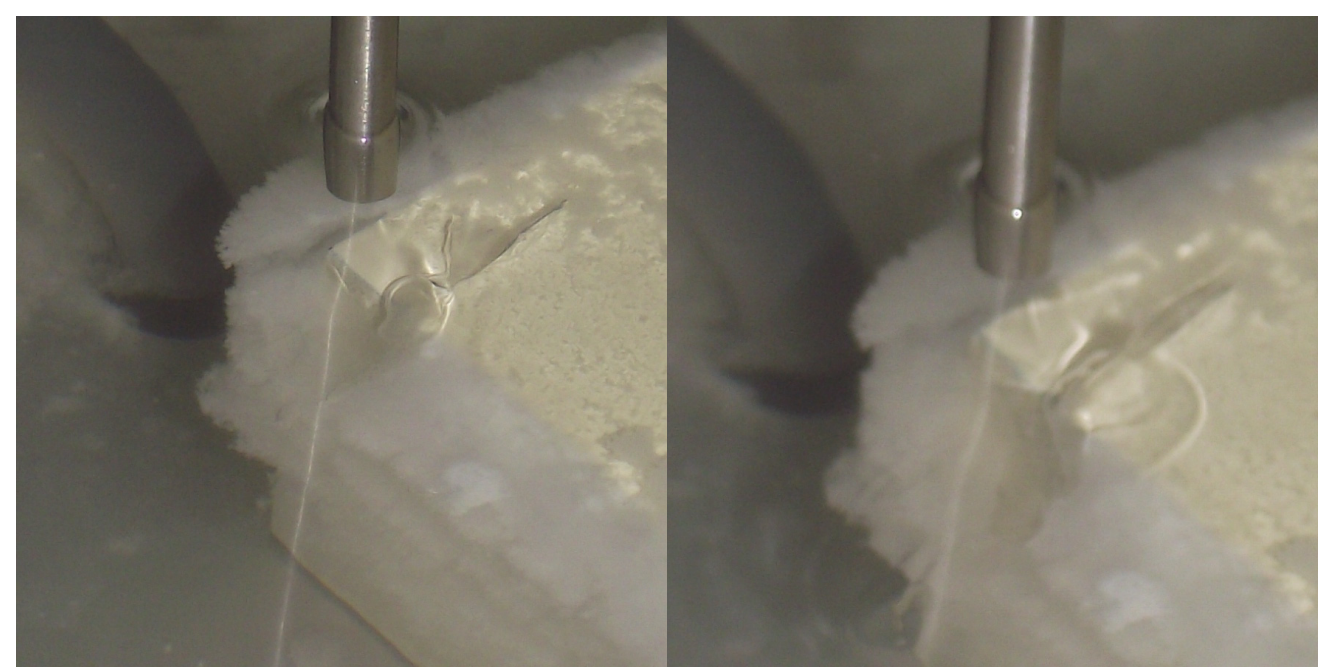

(c) $\bar{u}=0.080 \mathrm{~ms}^{-1}$

(d) $\bar{u}=0.160 \mathrm{~ms}^{-1}$

Figure 8. Effect of various jet velocities on the accreted ice.

accreted ice in this study. The lower limit of the snow density for the correlation of Yamanoi and $E_{n d o}{ }^{(50)}$ is $50 \mathrm{~kg} / \mathrm{m}^{3}$. This is slightly more than the mean snow density of the accreted ice in this study (Table 3). With a mean snow density $43 \cdot 6 \mathrm{~kg} / \mathrm{m}^{3}$, the correlation of Yamanoi and Endo $^{(50)}$ gives an internal shear strength of c. 55Pa. From a number of studies, it has been noted that the interface shear strength of ice is about one order of magnitude smaller than the internal shear strength of ice ${ }^{(52)}$. This suggests the interface shear strength could be in the unit place value range. This is within acceptable agreement with the interface shear strength for the accreted ice on subcooled surfaces submerged in fuel found in this study. 


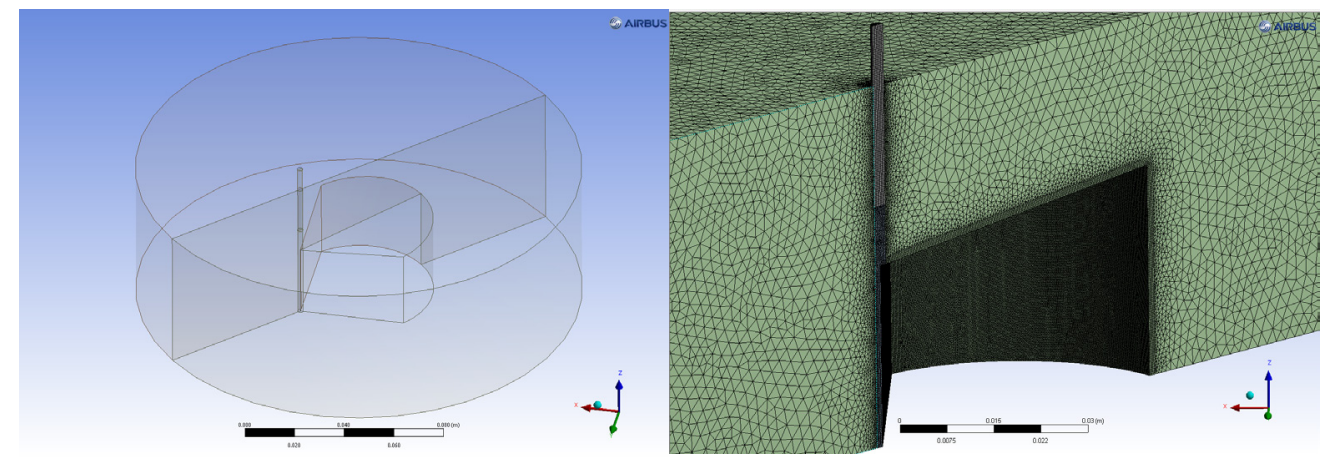

Figure 9. Full model layout showing the specimen block and the nozzle.

Figure 10. A close-up view of the CFD mesh.

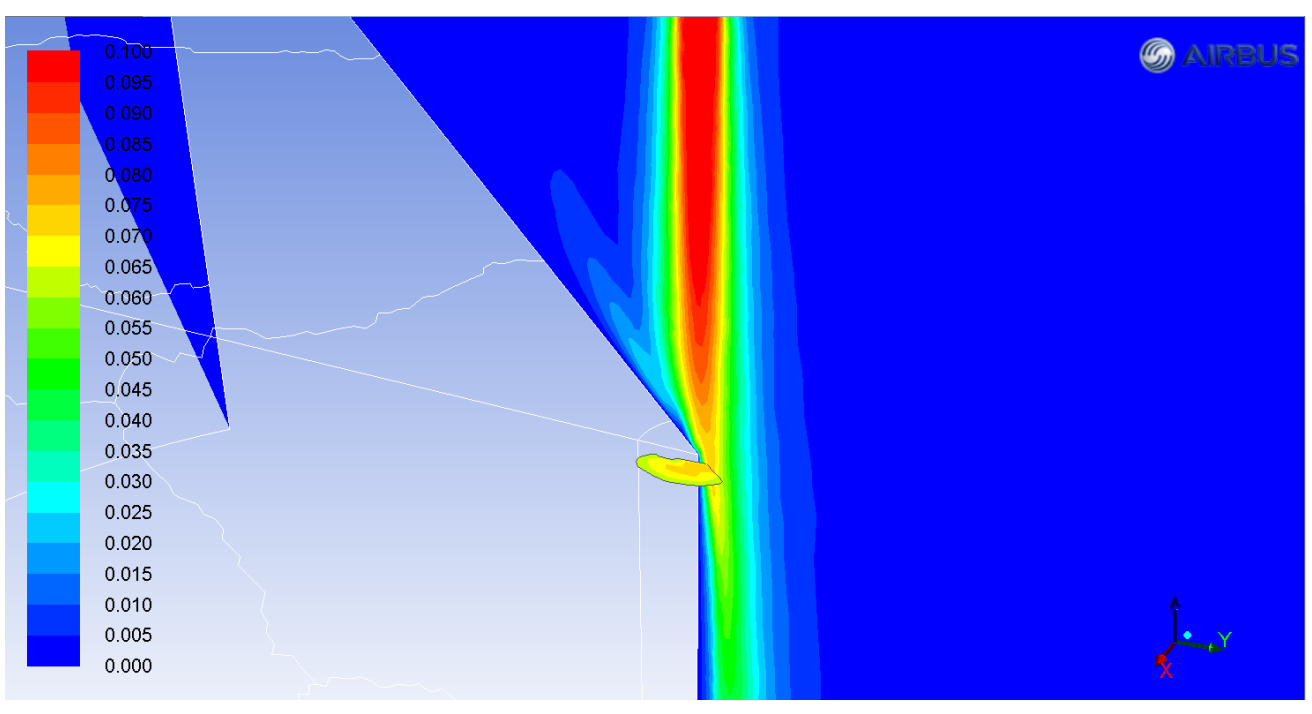

Figure 11. A close-up view of the velocity magnitude filled contours for $\bar{u}=0.080 \mathrm{~ms}^{-1}$.

\subsection{CONCLUSIONS}

Ice accretion on subcooled surfaces submerged in fuel had been simulated using a 20-litre aluminium tank with chilled plates and glass windows. The test tank was fitted with an array of thermocouples to measure temperatures at points of interest. A water replenishment system was implemented to sustain the ice accretion process. The water replenishment system continuously circulated fuel from the test tank through a two-bottle system which restored dissolved water to the fuel.

The accreted ice on subcooled surfaces submerged in fuel was found to be soft and fluffy. The accreted ice had a porosity of c. $0 \cdot 95$. There were no apparent differences between the ice deposit forming on the different surface finishes. With the limitations of the current experiment, it was not possible to determine the significance of these variations. It was possible to dislodge the accreted ice with a jet of fuel. From the jet velocity, the accreted ice interface shear strength is estimated to be c. $0 \cdot 36 \mathrm{~Pa}$ and c. $2 \cdot 19 \mathrm{~Pa}$ at the top surface and at the vertical surface of a specimen block, respectively. The discrepancy needs to be investigated further. 


\section{ACKNOWLEDGEMENTS}

This work formed part of a European Aviation Safety Agency (EASA) funded research project titled 'Water in Aviation Fuel under Cold Temperatures conditions - WAFColT'. The authors wish to thank Sasol for the supply of the fully synthetic Jet A-1.

\section{APPENDIX A: ICE CHARACTER PARAMETERS}

Snow density $\rho_{s}$ is one of several means to quantify snow character. Other parameters, such as porosity $n$, water content fraction $f_{w}$, specific gravity (SG) and snow-to-liquid ratio (SLR) may be used. The interrelationships of these parameters are given below for clarity.

$$
\begin{aligned}
& \mathrm{SLR}=\frac{\text { snow volume }}{\text { water volume }} \\
& =\frac{V_{s}}{V_{w}}=\frac{V_{s}}{m_{w} / \rho_{w}}=\frac{\rho_{w}}{\rho_{s}} \\
& \rho_{s}=\frac{\text { water mnss }}{\text { snow volume }} \\
& =\frac{m_{w}}{V_{s}}=\frac{\rho_{w}}{\mathrm{SLR}} \\
& n=\frac{\text { pore volume }}{\text { snow volume }} \\
& =\frac{V_{p}}{V_{s}}=\frac{V_{s}-V_{i}}{V_{s}}=1-\frac{\rho_{s}}{\rho_{i}} \\
& f_{w}=\frac{\text { water volume }}{\text { snow volume }} \\
& =\frac{V_{w}}{V_{s}}=\frac{\rho_{s}}{\rho_{w}}=\frac{1}{\mathrm{SLRR}} \\
& \mathrm{SG}=\frac{\text { snow density }}{\text { water density }} \\
& =\frac{\rho_{s}}{\rho_{w}}=\frac{1}{\operatorname{SLR}}
\end{aligned}
$$

A snow density $\rho_{s}$ of c. $44 \mathrm{~kg} / \mathrm{m}^{3}$ as that found for the accreted ice in this study corresponds to a SLR of c. 23 , a porosity $n$ of c. $0 \cdot 95$, a water content fraction $f_{w}$ of c. $0 \cdot 044$, and a specific gravity SG of c. $0 \cdot 044$.

\section{APPENDIX B: CFD MODELLING}

A CFD study was performed to yield the wall shear stress values exerted by the jets on the top surface and the vertical surface of the the specimen block. Figure 9 shows the full model layout of 
the CFD simulation. The modelling domain was only half of the full model by taking advantage of the symmetry plane in the full model. A hybrid mesh of just under 2.69 million elements was constructed for the modelling domain. The hybrid mesh consisted of a mixture of structured mesh regions and unstructured mesh regions combined together to cover the modelling domain in an effcient way in terms of number of elements and computation accuracy. Boundary layer mesh was deployed on the specimen block surfaces to better capture the vertical wall jet flow and the horizontal wall jet flow. Figure 10 shows a close-up view of the mesh. The hollowed-out region is the specimen block. Fine mesh was used in the jet trajectory region to ensure a high computation resolution for the free jet. Figure 11 shows a close-up view of velocity magnitude filled contours at the top of the vertical surface of the specimen block. It shows the results for a mean exit jet velocity $\bar{u}$ of $0 \cdot 08 \mathrm{~ms}^{-1}$.

\section{APPENDIX C: SHEAR STRENGTH}

There are two types of shear strength, internal shear strength and interface shear strength ${ }^{(53)}$. The internal shear strength is the maximum shear stress that a material can sustain prior to a shear fracture in the material. The interface shear strength is the maximum shear stress that an interface between two materials can sustain prior to a shear break at the interface.

The shear resistance of particulate materials, such as soil and snow, is derived from two components, bonding at particle contacts and the friction resistance between particles. The relationship is expressed in the equation known as the Coulomb's law of shear strength ${ }^{(32,40,41,53)}$ :

$$
\begin{aligned}
& \tau_{c}=\sigma_{n} \operatorname{Tan} \phi_{c}+\sigma_{c} \\
& \tau_{a}=\sigma_{n} \operatorname{Tan} \phi_{a}+\sigma_{a}
\end{aligned}
$$

Here $\tau_{c}$ is the internal shear strength; $\tau_{a}$ the interface shear strength; $\sigma_{n}$ the normal stress; $\sigma_{c}$ the cohesion of particles; $\sigma_{a}$ the adhesion of the interface; $\phi_{c}$ the internal friction angle; and $\phi_{a}$ the interface friction angle. Adhesion of the interface $\sigma_{a}$ is defined as interfacial bonds across the interface and is proportional to interface area ${ }^{(41)}$. Similarly, cohesion of particles $\sigma_{c}$ is determined largely by the number and size of the intergranular bonds ${ }^{(51)}$.

\section{REFERENCES}

1. Air Accidents Investigation Branch. Report on the accident to Boeing 777-236ER, G-YMMM, at London Heathrow Airport on 17 January 2008 - final report, Aircraft Accident Report 1/2010, Department for Transport, Hampshire GU11 2HH, UK, 2010.

2. Air Accidents Investigation Branch. Report on the accident to Boeing 777-236ER, G-YMMM, at London Heathrow Airport on 17 January 2008 - interim report 2, Aircraft Accident Report 1/2010, Department for Transport, Hampshire GU11 2HH, UK, 2009.

3. Air Accidents Investigation Branch. Report on the accident to Boeing 777-236ER, G-YMMM, at London Heathrow Airport on 17 January 2008 - interim report, Aircraft Accident Report 1/2010, Department for Transport, Hampshire GU11 2HH, UK, 2008.

4. Carpenter, M.D., Hetherington, J.I., Lao, L., Ramshaw, C., Yeung, H., Lam, J.K.-W., Masters, S. and BARLEY, S. Behaviour of water in aviation fuels at low temperatures, in: Morris, R.E., (Ed), 12th International Conference on Stability, Handling and Use of Liquid Fuels, 2011, 2, pp 1036-62, IASH 2011, Sarasota, Florida, US, 16-20 October 2011. ISBN 978-1-61839-764-5.

5. Lao, L., Ramshaw, C., Yeung, H., Carpenter, M.D., Hetherington, J.I., Lam, J.K.-W. and Barley, S. Behaviour of water in jet fuel in a simulated fuel tank, SAE Technical Paper, 2011, 2011-01-2794. doi:10.4271/2011-01-2794. 
6. Murray, B.J., Broadley, S.L. and Morris, G.J. Supercooling of water droplets in jet aviation fuel, Fuel, 2011, 90, (1), pp 433-5. doi:10.1016/j.fuel.2010.08.018.

7. Lam, J.K.-W., Hetherington, J.I. and CarPenter, M.D. Ice growth in aviation jet fuel, Fuel, 2013, 113, pp 402-6. doi:10.1016/j.fuel.2013.05.048.

8. Maloney, T.C. The collection of ice in Jet A-1 fuel pipes, Tech Rep, DOT/FAA/TC-TT12/29, Federal Aviation Administration, William J. Hughes Technical Center, Aviation Research Division, Atlantic City International Airport, New Jersey, US, 2012.

9. BAENa, S., LAWSOn, C.P. and LAM, J.K.-W. Dimensional analysis to parameterise ice accretion on mesh strainers, SAE Technical Paper, 2011, 2011-01-2795. doi:10.4271/2011-01-2795.

10. Baena-Zambrana, S., Repetto, S.L., Lawson, C.P. and Lam, J.K.-W. Behaviour of water in jet fuel - a literature review, Progress in Aerospace Sciences, 2013, 60, (0), pp 35-44. doi:10.1016/j. paerosci.2012.12.001.

11. Oreshenkov, A.V. Accumulation of water in jet fuels - mathematical modeling of the process, Chemistry \& Technology of Fuels \& Oils, 2004, 40, (5), pp 320-5. doi:10.1023/B:CAFO.0000046266.83408.d7.

12. Tomlinson, S., Barker, M., Venn, D., Hickson, L. and Lam, J.K.-W. Mathematical model of water contamination in aircraft fuel tanks, SAE Technical Paper, 2011, 2011-01-2540. doi:10.4271/2011-012540 .

13. European Aviation Safety Agency. WAFCOLT - water in aviation fuel under cold temperature conditions, specifications attached to the invitation to tender-EASA.2010.OP.07, 2010.

14. DAvies, P.L. Water dissolved in hydrocarbon fuels, in: 4th World Petroleum Congress, 4, June 6-15, Rome, Italy, 1955.

15. Coordinating Research Council. Handbook of aviation fuel properties, CRC report no. 635, 3rd ed, Warrendale, Pennsylvania 15096, US, Society of Automotive Engineers, Inc. (distributor), 2004.

16. Lam, J.K.-W., Carpenter, M.D., Williams, C.A. and Hetherington, J.I. Water solubility characteristics of current aviation jet fuels, Fuel, 2014, 133, pp 26-33. doi:10.1016/j.fuel.2014.04.091.

17. Ware, E.C., Schultz, D.M., Brooks, H.E., Roebber, P.J. and Bruening, S.L. Improving snowfall forecasting by accounting for the climatological variability of snow density, Weather \& Forecasting, 2006, 21, (1), pp 94-103. doi:10.1175/WAF903.1.

18. Baxter, M.A., Graves, C.E. and Moore, J.T. A climatology of snow-to-liquid ratio for the contiguous United States, Weather \& Forecasting, 2005, 20, (5), pp 729-44. doi:10.1175/WAF856.1.

19. Alcott, T.I. and Steenburgh, W.J. Snow-to-liquid ratio variability and prediction at a high-elevation site in Utah's Wasatch Mountains, Weather \& Forecasting, 2010, 25, (1), pp 323-37. doi:10.1175/2009WAF2222311.1.

20. Judson, A. and Doesken, N. Density of freshly fallen snow in the central Rocky Mountains, Bulletin of the American Meteorological Society, 2000, 81, (7), pp 1577-87. doi:10.1175/1520-0477 (2000)081<1577:DOFFSI $>2.3$.CO.

21. DuBĖ, I. From mm to cm-study of snow/liquid water ratios in Quebec, Tech Rep, Meteorological Service of Canada, Quebec, QC, Canada, 2003.

22. Roebber, P.J., Bruening, S.L., Schultz, D.M. and Cortinas, J.V. Jr Improving snowfall forecasting by diagnosing snow density, Weather \& Forecasting, 2003, 18, (2), pp 264-87. doi:10.1175/15200434(2003)018.

23. Bailey, M.P. and HaLlett, J. A comprehensive habit diagram for atmospheric ice crystals: confirmation from the laboratory, AIRS II, and other field studies, J Atmospheric Sciences, 2009, 66, (9), pp 2888-99. doi:10.1175/2009JAS2883.1.

24. Halfpenny, J.C. and Ozanne, R.D. Winter: an ecological handbook, 1st ed, Johnson Publishing Company, Boulder, Colorado 80301, US, 1989. ISBN 1-55566-036-3.

25. Meløysund, V., Leira, B., Høiseth, K.V. and Lisø K.R. Predicting snow density using meteorological data, Meteorological Applications, 2007, 14, (4), pp 413-23. doi:10.1002/met.40.

26. McClung, D.M. Direct simple shear tests on snow and their relation to slab avalanche formation, $J$ Glaciology, 1977, 19, (81), pp 101-9.

27. SChweizer, J. Laboratory experiments on shear failure of snow, Annals of Glaciology, 1998, 26, pp 97-102.

28. Abe, O., Xu, J., Liu, J., Hirashima, H., Mochizuki, S., Yamaguchi, S., Sato, T. and Sato, A. Shear strength of natural and artificial depth hoar layers, ISSW 2006 Proceedings, Marmot, CO, US, 2006, pp 7-14.

29. Sommerfeld, R.A. Instructions for using the $250 \mathrm{~cm}^{2}$ shear frame to evaluate the strength of a buried snow surface, USDA Forest Service Research Note, 1984, 466, pp 1-6. 
30. JAmieson, B. and Johnston, C.D. Evaluation of the shear frame test for weak snowpack layers, Annals of Glaciology, 2001, 32, (1), pp 59-69. doi:10.3189/172756401781819472.

31. Hefny, R., Kollar, L.E., Farzaneh, M. and Payrard, C. Adhesion of wet snow to different cable surfaces, in: 13th International Workshop on Atmospheric Icing of Structures, Andermatt, Switzerland, 2009.

32. Nakamura, T., Aвe, O., Нashimoto, R. and Оhта, T. A dynamic method to measure the shear strength of snow, J Glaciology, 2010, 56, (196), pp 333-8. doi:10.3189/002214310791968502.

33. Visser, C.W., Gielen, M.V., Hao, Z., Le GaC, S., Lohse, D. and Sun, C. Quantifying cell adhesion through impingement of a controlled microjet, Biophysical Journal, 2015, 108, (1), pp 23-31, doi:10.1016/j. bpj.2014.10.071.

34. Phares, D.J., Smedley, G.T. and Flagan, R.C. The wall shear stress produced by the normal impingement of a jet on a flat surface, $J$ Fluid Mechanics, 2000, 418, pp 351-75.

35. Eriksson, J.G., Karlsson, R.I. and Persson, J. An experimental study of a two-dimensional plane turbulent wall jet, Experiments in Fluids, 1998, 25, (1), pp 50-60. doi:10.1007/s003480050207.

36. Levin, O., Chernoray, V.G., Löfdahl, L. and Henningson, D.S. A study of the blasius wall jet, $J$ Fluid Mechanics, 2005, 539, pp 313-47. doi:10.1017/S0022112005005628.

37. Issa, J.S. Scaling of Convective Heat Transfer in Laminar and Turbulent Wall Jets with Effects of Freestream Flow and Forcing, PhD thesis, Department of Aerospace and Mechanical Engineering, The University of Arizona, Tucson, AZ 85721, US, 2006.

38. Ackerman, J.D., Ethier, C.R., Spelt, J.K., Allen, D.G. and Cottrell, C.M. A wall jet to measure the attachment strength of zebra mussels, Canadian J Fisheries \& Aquatic Sciences, 1995, 52, (1), pp 126-35. doi:10.1139/f95-012.

39. George, W.K., Abrahamsson, H., Eriksson, J., Karlsson, R.I., Löfdahl, L. and WosniK, M. A similarity theory for the turbulent plane wall jet without external stream, J Fluid Mechanics, 2000, 425, pp 367-411. doi:10.1017/S002211200000224X.

40. FöHN, P.M.B. Characteristics of weak snow layers or interfaces, in: Proceedings of the 1992 International Snow Science Workshop, Breckenridge, Colorado, US, 1992, pp 160-70.

41. Mellor, M. A review of basic snow mechanics, in: The International Symposium on Snow Mechanics, Grindelwald, Switzerland: IAHS-AISH Publication 114, 1974, pp 251-91.

42. Fortin, G., Beisswenger, A. and Perron, J. Centrifuge adhesion test to evaluate icephobic coatings, in: AIAA Atmosphere and Space Environments Conference, AIAA 2010-7837, Toronto, Ontario, Canada, American Institute of Aeronautics and Astronautics, 2010. doi:10.2514/6.2010-7837.

43. Kuinich, S.A. and Farzaneh, M. On ice-releasing properties of rough hydrophobic coatings, Cold Regions Science \& Technology, 2011, 65, (1), pp 60-4. doi:10.1016/j.coldregions.2010.01.001.

44. CASSIE, A.B.D. and BAXTER, S. Wettability of porous surfaces, Transactions of the Faraday Society, 1944, 40, pp 546-51. doi:10.1039/ TF9444000546.

45. Wenzel, R.N. Resistance of solid surfaces to wetting by water, Industrial \& Engineering Chemistry, 1936, 28, (8), pp 988-94. doi:10. 1021/ie50320a024.

46. Dong, W., Ding, J. and Zhou, Z.X. Experimental study on the ice freezing adhesive characteristics of metal surfaces, in: 51st AIAA Aerospace Sciences Meeting including the New Horizons Forum and Aerospace Exposition, AIAA 2013-0743, Aerospace Sciences Meetings, Grapevine (Dallas/Ft Worth Region), Texas, US, American Institute of Aeronautics and Astronautics, 2013. doi:10.2514/6.2013-743.

47. KIBLER, E.M. Determination of adhesive strength and freezing rate of ice on aircraft structures at subcooled temperatures, MS thesis, Department of Mechanical Engineering, North Carolina Agricultural \& Technical State University, Greensboro, North Carolina, US, 2013.

48. Hirashima, H., Nishimura, K., Yamaguchi, S., Sato, A. and Lehning, M. Avalanche forecasting in a heavy snowfall area using the snowpack model, Cold Regions Science \& Technology, 2008, 51, (2), pp 191-203. doi:10.1016/j.coldregions.2007.05.013.

49. RADKE, L.F. and HobBS, P.V. The strength-density relationship for dry snow, J Glaciology, 1967, 6, (48), pp 893-6.

50. Yamanor, K. and Endo, Y. Dependence of shear strength of snow cover on density and water content, Seppyo, 2002, 64, (4), pp 443-51. Text in Japanese.

51. Ballard, G.E.H. and Feldt, E.D. A theoretical consideration of the strength of snow, J Glaciology, 1965, 6, (43), pp 159-70.

52. Tusima, K. Adhesion theory for low friction on ice, in: GHRIB, T. editor, New Tribological Ways, chap. 15, InTech, 2011. ISBN 978-953-307-206-7.

53. MCCARTNEY, J.S., Zornberg, J.G. and Swan, R.H. Internal and interface shear strength of geosynthetic clay liners (GCLs), Geotechnical Research Report, Department of Civil, Environmental \& Architectural 
Engineering at the University of Colorado at Boulder, Boulder, CO 80309, US, 2002.

54. Haynes, W.M., Lide, D.R. and Bruno, T.J. CRC Handbook of Chemistry and Physics, 93rd ed, CRC press, 2012. ISBN 1439880492.

55. Palacios, J., Smith, E., Rose, J. and Royer, R. Instantaneous de-icing of freezer ice via ultrasonic actuation, AIAA J, 2011, 49, (6), pp 1158-67. doi:10.2514/1.J050143.

56. JeLlineK, H.H. Adhesive properties of ice, part 2, DTIC Accession Number AD0638344 62, US Army Snow Ice \& Permafrost Research Establishment, Corps of Engineers, Wilmette, Illinois, US, 1960.

57. GounI, R. A new technique to study temperature effects on ice adhesion strength for wind turbine materials, MS thesis, Department of Materials Science \& Engineering, Case Western Reserve University, Cleveland, OH 44106, US, 2011. 